\title{
Nitrogen dressing and nutrient absorption of lilies (asiatic hybrids) on sandy soils
}

\author{
J.H.G. SLANGEN 1 , G. J. KROOK 1 , C. H. M. HENDRIKS 2 \& N. A. A. HOF ${ }^{3}$ \\ 1. Dept. of Soil Science and Plant Nutrition, Wageningen Agricultural University, De Drei- \\ jen 3, 6703 BC Wageningen, Netherlands \\ 2 Bulb Research Centre, P.O. Box 85, 2160 AB Lisse, Netherlands \\ 3 Research Stations Breezand and Zwaagwijk, Tolweg 13, 1681 ND Zwaagdijk, Netherlands
}

Received 20 December 1988; accepted 18 August 1989

\begin{abstract}
The effect of amount and time of application of nitrogen on yield and nutrient uptake of three asiatic hybrids of lily was investigated. Efficiency of $\mathrm{N}$-uptake was determined on basis of soil and plant analysis after field experiments in 1983, 1984 and 1985. Leaching of fertilizers applied before planting induces low nutrient efficiencies in sandy soils. A split-up of the total N-dressings from March to June or April to July leads to a higher N-efficiency, though leaching of fertilizers because of a surplus of rain will easily occur. The amount of plant nutrients $(\mathrm{P}, \mathrm{K}, \mathrm{Ca}, \mathrm{Mg}$ and $\mathrm{Na}$ ) in mature plants of Aristo, Connecticut King and Enchantment are presented in relation with yield and $\mathrm{N}$-uptake.
\end{abstract}

Keywords: nitrogen dressing, lilium cultivars, nutrient uptake, nitrogen efficiency

\section{Introduction}

The relatively high amounts of nitrogen used for lilies on sandy soils in the Netheriands are preferably applied as a split dressing of $50-100 \mathrm{~kg}^{\mathrm{ha}-1}$ before planting and $75 \mathrm{~kg} \mathrm{ha}^{-1}$ in two or three equal portions in May and June (van der Boon \& Niers, 1986). Preliminary field experiments and data on $\mathrm{N}$-uptake show a low $\mathrm{N}$ efficiency. Nitrogen efficiency is defined here as the amount of extra nitrogen taken up by plants grown on dressed soil above the amount absorbed by plants grown on soil without nitrogen dressing divided by the amount of $\mathrm{N}$ dressed.

The low efficiencies were found in particular for the nitrogen dressed just before planting (March), a period with a surplus of natural precipitation. To explain this, it should be taken into account that with lilies development of bulb roots, just after planting, is followed by the development of sub-soil stem roots in May.

In the following sections the experiments carried out in 1983, 1984 and 1985 for the lily cultivars Aristo, Enchantment and Connecticut King will be reviewed. Yield and uptake of $\mathrm{N}$ are studied in relation to amount and time of nitrogen application. The amounts of the nutrients $\mathrm{P}, \mathrm{K}, \mathrm{Na}, \mathrm{Ca}$ and $\mathrm{Mg}$ absorbed by leaves and bulbs 
are measured and discussed with respect to variety, yield and $\mathrm{N}$ uptake.

\section{Materials and methods}

Bulbs of Aristo, Connecticut King and Enchantment were planted on beds of $2 \mathrm{~m}^{2}$ on a coarse textured calcareous soil at the Research Station 'Breezand'. Investigation of yield and nutrient uptake in these trials was based on 560000 plants per ha. $A$ basal dressing of $P$ and $K$ was supplied. The amounts of available nitrogen $\left(\mathrm{N}_{\min }\right.$ measured in samples taken in March were 12 and $13 \mathrm{~kg} \mathrm{ha}^{-1}$ for $0-25$ and $25-50 \mathrm{~cm}$ layers, respectively.

Nitrogen was dressed at four levels, i.e., $0,75,150$ and $225 \mathrm{~kg} \mathrm{ha}^{-1}$ and three application periods were chosen: $t_{1}=1 / 2$ of the $\mathrm{N}$ before planting (March) and 1/6 in May, June and July; $t_{2}=1 / 4$ of the $N$ in March (after planting), April, May and June; $t_{3}=1 / 4$ of the $\mathrm{N}$ in April, May, June and July. The treatment combinations were laid out at random in 3 blocks (parallels).

During the growing period, soil and plant samples were taken in May, June, July and September from plots with $\mathrm{N}$ equal to 0,75 and $150 \mathrm{~kg} \mathrm{ha-1}$ and with the application periods mentioned. At the final harvest in October all treatments were sampled. The sampling in September is chosen somewhat arbitrary to find the maximum uptake of nutrients. After September, part of the leaves were removed from the plots, mostly by wind.

Plant material of six plants was sampled (at the final harvest 100 plants) and divided in aerial (leaves and stems) and underground parts (bulbs, roots and subsoil stems). The material was cleaned (underground parts), weighed, dried and ground for chemical analysis ${ }^{1}$.

In soil samples, plant-available nitrogen $\left(\mathrm{N}_{\min }\right)$ was measured after extraction with $1 \mathrm{M} \mathrm{KCl}$. The moisture content of the soil samples was determined to calculate the nitrogen content on a dry-weight basis. Volumic weights were fixed at 1.4 and $1.5 \mathrm{~g} \mathrm{~cm}^{-3}$ for $0-25$ and $25-50 \mathrm{~cm}$ layers, respectively.

\section{Results and discussion}

From soil analysis it can be concluded that nitrogen supplied early, i.e. (in March) $\left(t_{1}\right)$ and March, April $\left(t_{2}\right)$, moves into deeper soil horizons. The increase of the dry weight of the bulbs up to the first harvest, in the middle of May, is small; N-uptake reaches from 5 to $10 \mathrm{~kg} \mathrm{ha-1}$. The interception of nutrients is determined by a small amount of roots, because stem roots only appear from half May. The nitrogen supplied from April onwards is used more effectively (Table 1). Splitting up the Namounts leads to higher yield and $\mathrm{N}$-uptake of all plant parts. Highest yields have been obtained with quarter split dressings from March to June of April to July at both 150 and $225 \mathrm{~kg} \mathrm{ha}^{-1}$ (Table 1), but in both years differences between treat-

\footnotetext{
1 Houba, V. J. G., J. J. van der Lee, I. Novozamsky \& I. Walinga, 1986. Soil and plant analysis (a series of syllabi). Part 5: Soil analysis procedures; Part 7; Plant analysis procedures. Dept. of Soil Science and Plant Nutrition, Wageningen Agricultural University, Wageningen.
} 
Table 1. Yield of bulbs $t$ (ha- ${ }^{-1}$ ) $\mathrm{N}$-efficiency (\%) of lilies (mean of 3 cultivars) as affected by amounts and split application of nitrogen in 1984 and 1985. Experimental Station 'Breezand' at Breezand.

\begin{tabular}{|c|c|c|c|c|c|c|c|c|c|c|}
\hline \multirow[b]{2}{*}{ before planting } & \multicolumn{10}{|c|}{ Nitrogen application (kg ha-1) } \\
\hline & 0 & 37.5 & 75.0 & 112.5 & 0 & 0 & 0 & 0 & 0 & 0 \\
\hline in March & 0 & 0 & 0 & 0 & 18.75 & 37.5 & 56.25 & 0 & 0 & 0 \\
\hline in April & 0 & 0 & 0 & 0 & 18.75 & 37.5 & 56.25 & 18.75 & 37.5 & 56.25 \\
\hline in May & 0 & 12.5 & 25.0 & 37.5 & 18.75 & 37.5 & 56.25 & 18.75 & 37.5 & 56.25 \\
\hline in June & 0 & 12.5 & 25.0 & 37.5 & 18.75 & 37.5 & 56.25 & 18,75 & 37.5 & 56.25 \\
\hline in July & 0 & 12.5 & 25.0 & 37.5 & 0 & 0 & 0 & 18.75 & 37.5 & 56.25 \\
\hline Total & 0 & 75 & 150 & 225 & 75 & 150 & 225 & 75 & 150 & 225 \\
\hline \multicolumn{11}{|l|}{ Yield (t ha-l } \\
\hline 841031 & 12.2 & 14.8 & 16.4 & 17.1 & 15.1 & 16.5 & 16.0 & 15.8 & 17.1 & 16.4 \\
\hline 851031 & 13.5 & 15.7 & 15.1 & 15.5 & 14.8 & 15.9 & 14.9 & 15.5 & 15.2 & 15.1 \\
\hline \multicolumn{11}{|c|}{$N$-efficiencyl $(\%)$} \\
\hline $840926^{2}$ & & 22.1 & 10.5 & 15.9 & 35.7 & 27.5 & 29.6 & 56.5 & 30.9 & 37.6 \\
\hline 850926 & & 36.1 & 29.9 & 22.7 & 19.5 & 21.5 & 19.1 & 34.3 & 21.6 & 26.2 \\
\hline
\end{tabular}

1 (uptake $\left(\mathrm{N}_{\mathrm{t}}-\mathrm{N}_{\mathrm{o}}\right) /$ dressing $\left.\mathrm{N}_{\mathrm{t}}\right) \times 100$.

2 September sampling: maximum nutrient uptake.

ments except with zero nitrogen were not significant. As can be seen from Table 1, the application of nitrogen from April onwards $\left(\mathrm{t}_{3}\right)$ gives the highest $\mathrm{N}$-efficiency in 1984. Weather conditions during a short period, i.e. the high rainfall in May and June 1985 , expose low N-efficiencies for treatment $2\left(t_{2}\right)$, whereas the early application $\left(t_{l}\right)$ gives a relatively higher efficiency in 1985 as compared to 1984 . In this respect the dressings are most profitable in July $\left(t_{1}\right)=1 / 6, t_{2}=0$ and $t_{3}=1 / 4$ ), when the crop is in full growth.

As differences between $\mathrm{N}$-treatments are not bound to cultivar, the results of the three cultivars were combined.

The aim of less leaching and $\mathrm{N}$ application in accordance with crop needs has to be achieved for lilies on sandy soils by a small amount or no nitrogen before planting and split applications at short intervals probably extending into the month of August. A total of $150 \mathrm{~kg} \mathrm{ha}^{-1}$ broadcast nitrogen, as advised nowadays, gives a sufficient safeguard against variable weather conditions. Applications of (small amounts of) fertilizers combined with irrigation water, so-called fertigation as practized for vegetable crops (Bakker et al., 1984; Slangen et al., 1988), might be useful too with crops as lilies grown for bulb production.

As a second topic of this research the amounts of nutrients absorbed in 1983-1985 by 3 cultivars of lilies at the so-called leaf maximum are presented with respect to yield and $\mathrm{N}$-uptake (Table 2). As differences between cultivars are not bound to level of distribution of $\mathrm{N}$-application, the results of the different $\mathrm{N}$-treatments (except the zero treatment) were combined. The nutrient uptake of Aristo is lowest as an average, partly due to lower bulb yields. 


\section{J. H. G. SLANGEN ET AL.}

Table 2. Yield of bulbs ( $\mathrm{t} \mathrm{ha-1)}$ and nutrients absorbed $\left(\mathrm{kg} \mathrm{ha}^{-1}\right.$ (mean of all $\mathrm{N}$-treatments except zero treatment) by leaves + bulbs of three cultivars of lilium (Aristo, Connecticut King and Enchantment) at Experimental Station 'Breezand' at Breezand.

\begin{tabular}{|c|c|c|c|c|c|c|c|c|}
\hline \multirow[t]{2}{*}{ Cultivar } & \multirow[t]{2}{*}{ Year } & \multirow{2}{*}{$\begin{array}{l}\text { Yield } \\
\left(\mathrm{ha}^{-1}\right)\end{array}$} & \multicolumn{6}{|c|}{ Nutrients absorbed (kg ha-1) } \\
\hline & & & $\mathbf{N}$ & $\mathrm{P}$ & K & $\mathrm{Na}$ & $\mathrm{Ca}$ & $\mathrm{Mg}$ \\
\hline \multirow[t]{3}{*}{ Aristo } & 1983 & 13.2 & 79 & 8 & 86 & 8 & 24 & 5 \\
\hline & 1984 & 16.1 & 59 & 12 & 118 & 11 & 44 & 8 \\
\hline & 1985 & 13.3 & 67 & 13 & 102 & 7 & 43 & 8 \\
\hline Connecticut & 1983 & 14.4 & 93 & 12 & 84 & 9 & 35 & 7 \\
\hline \multirow[t]{2}{*}{ King } & 1984 & 12.9 & 76 & 14 & 124 & 14 & 61 & 10 \\
\hline & 1985 & 16.5 & 91 & 18 & 158 & 14 & 91 & 15 \\
\hline \multirow[t]{3}{*}{ Enchantment } & 1983 & 15.1 & 98 & 16 & 98 & 7 & 37 & 6 \\
\hline & 1984 & 16.5 & 71 & 18 & 111 & 11 & 58 & 8 \\
\hline & 1985 & 15.6 & 92 & 22 & 127 & 12 & 65 & 11 \\
\hline
\end{tabular}

\section{References}

Bakker, M.J., J. H. G. Slangen \& W. Glas, 1984. Comparative investigation into the ef fect of fertigation and of broadcast fertilization on the yield and nitrate content of lettuce (Lactuca sativa L.) Netherlands Journal of Agricultural Science 32: 330-333.

Slangen, J. H. G., H. H. H. Titulaer \& W. Glas, 1988. The importance of fertigation for the improvement of N-fertilizer use efficiency in lettuce culture. Acta Horticulturae 222: 135-146.

This synopsis is based on a report entitled 'Stikstof-bemesting bij lelies' bij J. H. G. Slangen, C. H. M. Hendriks \& N. A. A. Hof. LBO Report Nr 61, Bulb Research Centre, Lisse, Netherlands, 1987, 73 pp., 26 tables, 15 figs., 13 refs., 3 appendices, in Dutch. Available as paper copy (order R096), $f 25$ including portage) at: NARD, c/o Pudoc, P.O. Box 4, 6700 AA Wageningen (telex 45015 bluwg $\mathrm{nl}$ ). 